Institut für Ost- und
Südosteuropaforschung
Institute for East and
Southeast European Studies

Arbeitsbereich Ökonomie

IOS Working Papers

No. 362 January 2017

\title{
Lending Conditions in EU: The Role of Credit Demand and Supply
}

Svatopluk Kapounek *, Zuzana Kučerová ${ }^{* *}$, and Jarko Fidrmuc ${ }^{* * *}$

\footnotetext{
${ }^{*}$ Mendel University in Brno, Czech Republic. Full corresponding adress: Mendel University in Brno, Faculty of Business Economics, Zemedelska 1, 61300 Brno, Czech Republic, email: kapounek@mendelu.cz, Phone: +420 545132 444, Fax: +420 545132 450. ${ }^{* *}$ Technical University of Ostrava, Faculty of Economics, Sokolská třída 33, Ostrava, Czech Republic, e-mail: zuzana.kucerova@vsb.cz. ${ }^{* \star \star}$ Zeppelin University Friedrichshafen, and Institute of East and Southeast European Studies (IOS), Germany, IES, and Charles University in Prague, Czech Republic, e-mail: jarko.fidrmuc@zu.de.
} 
Institut für Ost- und

Südosteuropaforschung

Institute for East and

Southeast European Studies

Landshuter Straße 4

D-93047 Regensburg

Telefon: (0941) 94354-10

Telefax: (0941) 94354-27

E-Mail: info@ios-regensburg.de

Internet: www.ios-regensburg.de

ISSN: 2199-9465 


\section{Contents}

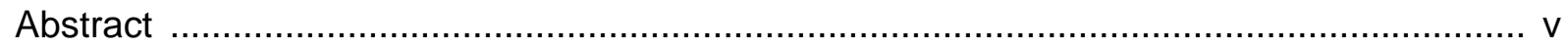

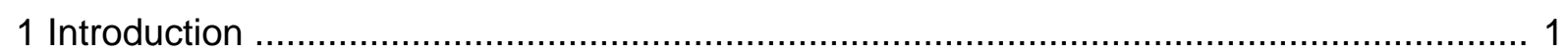

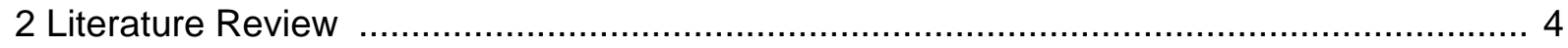

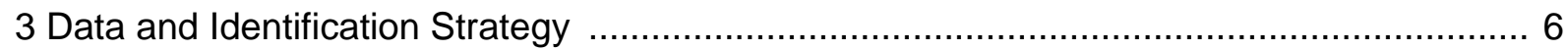

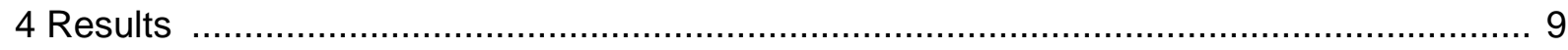

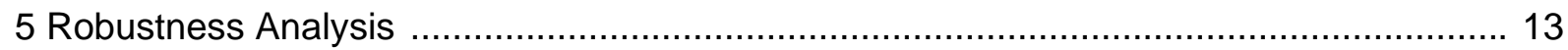

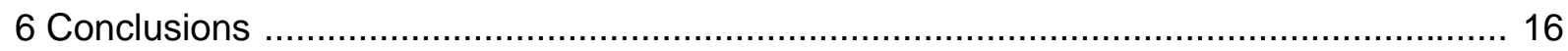

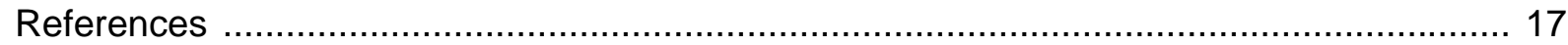

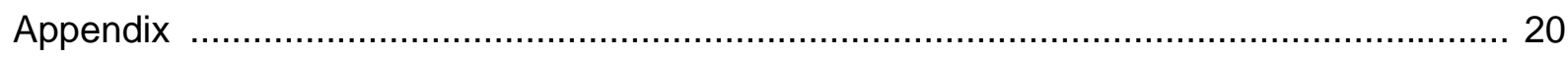

\section{List of Tables}

Table 1: Macroeconomic shocks and institutions, fixed effects model ............................... 9

Table 2: Macroeconomic shocks and institutions: 2SLS fixed effects model ..................... 11

Table 3: Impact of shocks on large and small banks, fixed effects model ......................... 14

Table 4: Macroeconomic shock and the impact of the crisis, 2SLS fixed effects model ...... 15

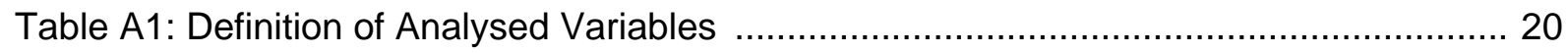

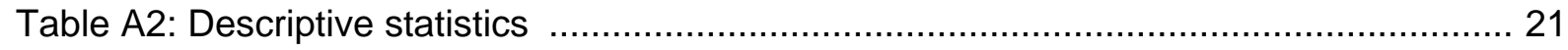

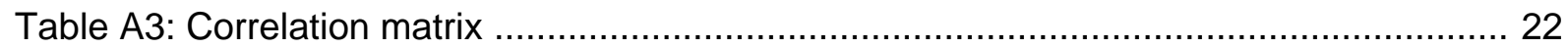





\begin{abstract}
We analyse the bank lending activity after the financial crisis and focus on bank-specific supply factors. Using a rich microeconomic dataset from Bankscope and macroeconomic shocks data, we employ OLS and 2SLS fixed effects models with banking controls, macroeconomic shocks and institutional quality. The banks' loan-rate spreads increased despite the recent policy of low interest rates and quantitative easing. We use the bank asset quality as instruments to capture exogenous changes in loan supply. The empirical evidence shows that loan-rate spread and through this the supply of loans is negatively affected by a low asset quality and capital ratios.
\end{abstract}

JEL-Classification: E58, G21, G28

Keywords: bank lending; loans; financial vulnerability; loan-rate spreads; institutions; macroeconomic shocks

This research was funded by the Czech Science Foundation via grant No. P403/14-28848S "Financial Crisis, Depreciation and Credit Crunch in CEECs" and by the VSB-Technical University of Ostrava via grant No. SP2016/101 "Monetary, Fiscal and Institutional Aspects of Macroeconomic Policy in Selected Countries". We benefited from comments and suggestions made by Jesus Crespo Cuaresma, Makram El-Shagi, Angela De Martiis, Philip Molyneux, Christopher Hartwell and other participants of the 15th International Conference on Finance and Banking in Prague, October 2015, the 2nd HenU/INFER Workshop on Applied Macroeconomics, March 2016, and Joint Annual Meeting of the Slovak Economic Association and the Austrian Economic Association in Bratislava, May 2016. 



\section{Introduction}

The financial crisis in 2007-2008 has caused a severe banks' liquidity shortage and a subsequent credit crunch. Several authors (e.g. Gambacorta and Marques-Ibanez, 2011) note that the crisis revealed that macroeconomic research has so far neglected the importance of financial intermediaries (banks) as a potential source of frictions in the monetary transmission mechanisms. This paper aims to extend this line of research. Since the crisis, there is a vast body of literature on the global transmission of past financial crises which mostly finds strong evidence for the transmission of global shocks to liquidity and global capital flows (e.g. Brunnermeier, 2009; Brunnermeier and Pedersen, 2009; Calvo, 2009 or Kalemli-Ozcan et al., 2013). Previous research on this topic documents the existence of a worldwide slowdown of credit flows which has negatively affected investment activities and growth.

However, the traditional transmission channels may have been weakened, in recent years, by financial innovations, deregulation, an increasing bank disintermediation and financial distress, as a result of the financial crisis (Gambacorta and Marques-Ibanez, 2011). Loan securitisation influenced these channels as a result of increasing bank balance sheet liquidity (Loutskina and Strahan, 2009). The crisis has influenced both lenders and borrowers through different channels. There are two partial effects within the credit channel (Kishan and Opiela, 2000). First, macroeconomic shocks or tight monetary policy have an impact on borrowers' balance sheets through the raise of interest rates (broad credit channel). Thus, shocks affect the cost and availability of credit and limit the supply of credit. Second, tight monetary policy can influence the level of bank capital as it increases the cost of funds faced by banks and, in turn, the cost of funds faced by borrowers as a part of the bank lending channel (narrow credit channel). Lastly, higher capital requirements faced by banks also influence the level of bank capital and the ability of banks to supply credit. Moreover, deBondt and MarquesIbanez (2005) argue that the bank lending channel has also changed due to the developments in the financial markets, e.g. alternative forms of funding for firm in the corporate bond market.

In particular, tighter liquidity conditions, output decline and increased credit risk have revealed a high degree of heterogeneity within the EU. Moreover, monetary policy-makers' choices of tools and actions may differ greatly depending on whether the aim is to affect loan supply, loan demand, or both. However, the estimation of supply and demand factors is one of the most difficult issues because nearly all factors may have simultaneous effects on both the supply and demand for credit. After the financial crisis, the ECB and nearly all EU central banks decreased their policy interest rates and provided additional liquidity to banks through open market operations and, more recently, through the policy of quantitative easing. Despite the 
reduction of policy interest rates, the banks did not change loan rates to the same degree. Instead, they responded to increased risk by higher interest margins. Therefore, it is particularly important to investigate how the supply of loans is influenced by bank risk (or higher risk premia) and asset quality.

The consequences of the current crises in the Euro area contributed to the rising fear that capital needs and funding pressures faced by Western European banks may intensify pressure to deleverage in this region. Therefore, a better understanding of the transmission process is one of the most important issues related to the recent financial crisis, especially from the perspective of a European recovery. This reflects also the fact that European economies are more reliant on bank credit and bank intermediation of savings than the United States and the rest of the world.

We analyse several effects of liquidity changes on credit flows which are driven by the level of capital of individual banks. A sufficiently capitalised bank or a bank with an access to additional sources of capital should be able to accommodate possible funding liquidity shocks without reducing its assets and lending activity. However, the banks have often to adjust their assets in order to keep a constant capital ratio. In such a case, a bank loss may result in a reduction in the level of assets with the required decrease equal to the size of the capital loss scaled up by the inverse of its capital/leverage ratio.

Therefore, the objective of this paper is to identify the link between macroeconomic shocks and related bank risk, the institutional environment and the responses of the banking sector to the financial crisis within the EU countries. We focus on the impact of bank liquidity conditions and asset quality which are supply factors of the bank lending activities in the EU. In particular, we use loan-rate spreads as a proxy for loan prices (Bassett et al., 2014). Similarly to Cosimano and Hakura (2011) and Barajas et al. (2015), we can see that the semielasticity of loan demand has become negative and high since the crisis. Finally, in our analysis, we also analyse the impact of some selected institutional factors. The advantage of our data set is that we can use a comparatively long time dimension (2000 to 2013), but also that we can compare the importance of these factors to the situation before and after the financial crisis in order to assess the period of loose monetary policy after the crisis. Moreover, we also distinguish between large and small banks in the monetary transmission process. The results of our analysis indicate that the lending process of large banks is more influenced by higher bank risk.

Our paper makes three main contributions to the literature on lending activities in the EU. First, we identify the main supply and demand factors influencing lending activity of European banks. According to our results the main supply factor is the loan rate spread (as a proxy of 
market risk). Second, we distinguish between large and small banks, partly following the approach of Kashyap and Stein (1995; 2000) or Gambacorta and Marques-Ibanez (2011). Finally, we examine both the pre-crisis and post-crisis period in order to capture the change in the behaviour of banks. Our results suggest that supply factors are particularly important in case of large banks, while the behaviour of small banks is more influenced by demand factors.

The remainder of the paper is organised as follows. Section 2 contains the literature review. An overview of methods and data is provided in Section 3 where the empirical model is introduced and the variables are defined. Section 4 presents the results of the econometric model. In Section 5, the robustness analysis is performed. Section 6 presents some concluding remarks and discusses some policy implications. 


\section{Literature Review}

There are four main approaches, used in the recent literature, to analyse whether the lending activity of the commercial banking system is influenced by demand factors or supply factors: (1) bank lending surveys related to lending standards set by bank managers for short horizons (Rajan, 1994; Asea and Blomberg, 1998; Berger and Udell, 2004; Ruckes, 2004), (2) the semielasticity of loan demand using instrumental variables (Cosimano and Hakura, 2011; Bassett et al., 2014; Barajas et al., 2015), (3) the disequilibrium model of credit demand and supply to test the credit crunch hypothesis (Clower, 1965; Barro and Grossman, 1971; Benassy, 1975; Drèze, 1975; Maddala and Nelson, 1974), (4) two cointegrating relationships representing loan demand and supply (Hülsewig et al., 2006; de Mello and Pisu, 2010).

In addition, there are different transmission channels and bank lending activity determinants discussed in the literature. The first studies on bank lending channels focus on banks in the United States. Kashyap and Stein (1995) find that US banks lower lending in reaction to monetary policy tightening. Moreover, smaller banks with less access to uninsured funds are more strongly influenced by monetary policy actions. Kashyap and Stein (2000) show that small and less liquid banks with low securities holdings react more strongly to monetary policy shocks. Kishan and Opiela (2000) document that banks in the United States limited the supply of loans after monetary policy tightening as a result of low levels of bank capital, and that small and less-capitalised banks are more responsive to monetary policy actions.

Moreover, the level of bank capital was often identified as a key factor for the linkage between financial conditions and real economic activity. Gambacorta and Marques-Ibanez (2011) find that selected bank-specific characteristics can have a significant impact on the supply of credit. Furthermore, banks with a lower level of core capital (measured using a Tier 1 ratio), a higher liquidity dependence on market funding and non-interest sources of income lowered the supply of loans even further during the crisis with respect to other banks (Fidrmuc et al., 2015). Popov and Udell (2012) present an empirical analysis of 16 emerging European countries. They analyse the sensitivity of credit supply to banks' financial conditions and find that a decline in banking equity, Tier 1 , capital and losses on financial assets reduced the credit flows to firms during the crisis. Berrospide and Edge (2010) apply a number of different panel estimation methods to examine how bank capital influences the extension of a bank credit. Their empirical results show modest effects of capital shortfalls and capital ratios on loan growth. They find that more important roles of other factors, such as economic activity and increased perception of riskiness by banks, should be studied. 
The different effects of liquidity changes on capital flows are given by the quality of domestic institutions, country risk, strength of domestic macroeconomic fundamentals and other factors. Fratzscher (2012) finds that these effects are highly heterogeneous across countries. Djankov et al. (2007) show that creditor protection is associated with more developed financial systems. In a related study, Djankov et al. (2008) show that financial development is also related to debt enforcement rules. Property rights and enforcement rules are especially important for transition economies where new institutions were created (Raiser et al., 2000). Beck and Levine (2002) confirm the impact of the overall financial development and legal system efficiency on capital allocation and also industry growth and new establishment formation across industries. In fact, they recommend focusing on institutional variables, i.e. as a more useful approach. Uzunkaya (2012) studies the role of institutions in the context of the structure of a financial system and concludes that market-based systems work better in low-rule of law countries, while bank-based systems are more efficient in high-rule of law countries. Moreover, the level of financial development also plays an important role as the market-based system works better in financially developed economies, while the bank-based system is better in financially underdeveloped economies.

As Altunbas et al. (2010) claim, bank risk should be taken into account when analysing the functioning of the bank lending channel. These authors analyse the set of European Union banks and conclude that bank risk is an important factor determining the supply of bank loans and thus it has to be isolated from the effects of monetary policy changes. Numerous authors analyse the impact of a variety of determinants which influence interest rate spreads. Ho and Saunders (1981) develop a theoretical model of the determination of interest rate spreads, which shows that spreads are determined by the degree of risk aversion of a bank management, the market structure of the banking sector, the size of bank transactions and the variance of money market interest rates. In addition, Allen (1988) states that interest rate spreads are determined by the risk premium and the monopoly power of a bank. Were and Wambua (2014) discuss other factors having an impact on spread, e.g. regulation, efficiency of banks, liquidity of banks and lastly, economic factors. However, as Entrop et al. (2015) postulate, banks increase loan interest rates and fees and decrease deposit interest rates and fees according to the size of the maturity gap (as a result of the maturity structure of an individual bank), i.e. banks holding long-term loans in their balances increase loan interest rates and fees in order to compensate for the risk they undertake. 


\section{Data and Identification Strategy}

Our unbalanced panel on the European banks includes annual balance sheet data on 5176 commercial banks in EU27 between 2000 and 2013 (see Aables A.1 to A3 for variable definitions, basic descriptive statistics and correlations). The bank data is provided by the Bureau van Dijk, Bankscope database. We mostly focus on gross loan to asset ratio and loan-rate spread. The latter is calculated as a difference between interest income to gross loans (of individual banks) and money market interest rates. The higher the level of the spread, the higher the divergence of the individual banks' interest rates from the market interest rate. In other words, the spread is a proxy for market risk. Moreover, it can identify a credit crunch when the supply of bank loans is mainly driven by the supply and to a lesser degree by demand factors. Therefore, following Allen (1988), we do not use the traditional definition of the interest spread as a difference between the interest rates charged to borrowers and the interest rate paid to lenders. Thus, the spreads are influenced by the risk premium, and in case of risk neutrality the spreads are at a low level, while in case of increased risk the banks charge the uncertainty of loans in their interest rates.

Furthermore, we consider several bank specific variables which describe asset quality as a result of the past risk and management strategy of the banks. Following Bassett et al. (2014), we use these variables as instruments to identify the exogenous variation of supply factors. The capital adequacy requirements, Tier 1, reflect the ability of the banking sector to absorb shocks arising from economic or financial stress. In other words, it measures the extent to which a bank has sufficient capital reserves relative to the risk of its activities. The ratio of impaired loans to gross loans is used as a measure of low-quality, or non-performing, loans. For all bank-specific variables, we identify and remove the outliers in the $1 \%$ and $99 \%$ percentile. The data (except interest rates) were transformed using logs.

Moreover, we merge the individual bank data with macroeconomic and institutional data sets. Macroeconomic shocks include several economic activity indicators (GDP, investment defined as the gross capital formation, consumption, unemployment), inflation rate measured by the harmonised index of consumer prices (HICP). The macroeconomic shocks were obtained from the online Eurostat database (Eurostat, 2015). The indicators of macroeconomic shocks proxy the demand factors (i.e. the demand for bank loans) while the indicators of central bank activity and interest rate spread represent the supply factors (i.e. the supply of bank loans).

The institutional environment was analysed by several indicators which are part of the Economic Freedom Composite Index (Heritage Foundation). Since the economic theory cannot suggest specific institutional variables influencing bank lending activities, we use the 
Bayesian Model Averaging approach to identify the most robust institutional variables (the details are available upon request). According to our results we use two institutional variables in our models. Investment freedom which evaluates the restrictions imposed on the investments. This indicator is defined so that the higher the value of the indicator, the lower the restrictions and the higher the investment freedom is in the analysed country. Similarly, the monetary freedom index is a combination of a measure of price stability with an assessment of price controls which distort market activity. The higher the value of the index, the higher the freedom (the value of 100 denotes maximum freedom).

Using this broad and detailed data set, we focus on the share of gross loans to total assets of a bank $i$ in time $t$. The baseline estimation is specified as

$$
\text { loans }_{i t}=\beta_{b} \text { spread }_{i t}+\sum_{s=1}^{S} \beta_{s} \text { shocks }_{s c t}+\sum_{l=1}^{L} \beta_{l} \text { inst }_{l c t}+\mu_{i}+\theta_{t}+\varepsilon_{i t},
$$

where the variable spread represents loan-rate spread of a bank $i$ in time $t$. The second set of variables, denoted by shocks, represents selected macroeconomic shocks, $s$, in a country $c$. The last set of variables, inst, includes institutional determinants (e.g. economic and monetary freedom). Finally, we include bank fixed effects, $\mu$, time effects, $\theta$, and a possibly heteroscedastic residual, $\varepsilon$. We apply fixed effect estimator, using the property that the time and bank fixed effects cover a large part of the endogeneity bias, which is either time or bank invariant.

Second, we consider that spreads and gross loans may be endogenous. Following the empirical concept introduced by Bassett et al. (2014), we use asset quality and financial strength indicators, as the exogeneous instruments in a regression of loan quantities on loan prices represented by loan-rate spreads:

$$
\begin{aligned}
& \text { loans }_{i t}=\beta_{b} \text { spread }_{i t}+\sum_{s=1}^{S} \beta_{s} \text { shocks }_{s c t}+\sum_{l=1}^{L} \beta_{l} \text { inst }_{\text {lct }}+\mu_{i}+\theta_{t}+u_{i t}, \\
& \text { spread }_{i t}=\sum_{k=1}^{K} \beta_{k} \text { quality }_{k i t}+\sum_{s=1}^{S} \beta_{s} \text { shocks }_{\text {sct }}+\sum_{l=1}^{L} \beta_{l} \text { inst }_{l c t}+\mu_{i}+\theta_{t}+v_{i t},
\end{aligned}
$$

where the loan-rate spread is correlated with the instruments on bank asset quality, quality, which are not related directly to gross loans. To test for exogeneity of the instruments we apply the Hansen test for over-identifying restrictions (Hansen, 1982), and Kleibergen-Paap Lm statistic (Kleibergen and Paap, 2006) of underidentification to test whether the excluded instruments are correlated with the endogenous regressors. 
In the robustness analysis, we differentiate between small and large banks, where large banks represent banks with total assets to GDP over the median or the third tertile in country $c$. For the definition of large banks we use the distribution of bank size (assets scaled by GDP per capita) in each particular year. Additionally, we differentiate between the pre-crisis and postcrisis periods to emphasize a widening loan-rate spread and an easing of monetary policy after the year 2007. We focus especially on the development of the coefficient for loan-rate spread. In particular, a large decrease in such parameters indicates that the adjusted changes in asset quality and financial strength capture shifts in loan supply. 


\section{Results}

Table 1 presents the results of the first six specifications that vary according to the inclusion of macroeconomic shocks (GDP, investment, consumption, unemployment) and institutional determinants (investment freedom, monetary freedom). In particular, we use several indicators of macroeconomics shocks which we include one-by-one in specifications (1) to (3). In the second step, specifications (4) to (6) include selected macroeconomic shocks jointly with institutional determinants. All specifications include the indicators on loan-rate spread and HICP. Our results show that inflation tends to accelerate lending activities possibly through higher loan demand. Investments do not determine significantly bank lending activities, which may reflect that general investment conditions are highly stable in the analysed countries and fully covered by fixed effects. The positive impact of GDP and consumption, as well as negative impact of unemployment, confirms a cyclical pattern of loans.

Table 1: Macroeconomic shocks and institutions, fixed effects model, 2000-2013

\begin{tabular}{|c|c|c|c|c|c|c|}
\hline & \multicolumn{6}{|c|}{ Dependent variable: Gross Loans to Total Assets (ln) } \\
\hline & (1) & (2) & (3) & (4) & (5) & (6) \\
\hline Loan-rate Spread & $\begin{array}{l}-0.002^{* * *} \\
(0.000)\end{array}$ & $\begin{array}{l}-0.002^{* * *} \\
(0.000)\end{array}$ & $\begin{array}{l}-0.002^{* * *} \\
(0.000)\end{array}$ & $\begin{array}{l}-0.002^{* * *} \\
(0.000)\end{array}$ & $\begin{array}{l}-0.002^{* * *} \\
(0.000)\end{array}$ & $\begin{array}{c}-0.002^{* * *} \\
(0.000)\end{array}$ \\
\hline HICP (ln) & $\begin{array}{l}0.775^{* * *} \\
(0.164)\end{array}$ & $\begin{array}{l}0.628^{* * *} \\
(0.189)\end{array}$ & $\begin{array}{l}1.155^{* * *} \\
(0.181)\end{array}$ & $\begin{array}{l}0.629^{* * *} \\
(0.183)\end{array}$ & $\begin{array}{l}0.554^{* * *} \\
(0.204)\end{array}$ & $\begin{array}{l}1.006^{* * *} \\
(0.203)\end{array}$ \\
\hline GDP (ln) & $\begin{array}{l}0.675^{* * *} \\
(0.110)\end{array}$ & & & $\begin{array}{l}0.668^{* * * *} \\
(0.112)\end{array}$ & & \\
\hline Investment (ln) & & $\begin{array}{c}-0.135 \\
(0.087)\end{array}$ & & & $\begin{array}{c}-0.110 \\
(0.084)\end{array}$ & \\
\hline Consumption (ln) & & $\begin{array}{l}1.064^{* * *} \\
(0.237)\end{array}$ & & & $\begin{array}{l}0.988^{* * *} \\
(0.233)\end{array}$ & \\
\hline Unemployment (ln) & & & $\begin{array}{l}-0.043^{* * *} \\
(0.015)\end{array}$ & & & $\begin{array}{c}-0.046^{* * *} \\
(0.016)\end{array}$ \\
\hline Monetary & & & & $0.232^{*}$ & 0.129 & $0.274^{* *}$ \\
\hline freedom (ln) & & & & $(0.127)$ & (0.123) & $(0.128)$ \\
\hline Investment & & & & $0.107^{* *}$ & $0.073^{*}$ & $0.116^{* * *}$ \\
\hline freedom (ln) & & & & $(0.043)$ & $(0.041)$ & $(0.044)$ \\
\hline Constant & $\begin{array}{l}-2.537^{* * *} \\
(0.948)\end{array}$ & $\begin{array}{l}-3.052^{* * *} \\
(0.928)\end{array}$ & $\begin{array}{c}-1.025 \\
(0.807)\end{array}$ & $\begin{array}{c}-3.327^{* * *} \\
(0.966)\end{array}$ & $\begin{array}{l}-3.369^{* * *} \\
(0.954)\end{array}$ & $\begin{array}{c}-2.046^{* *} \\
(0.893)\end{array}$ \\
\hline Year dummies & YES & YES & YES & YES & YES & YES \\
\hline Number of Obs. & 33,326 & 33,326 & 33,338 & 33,326 & 33,326 & 33,338 \\
\hline Number of Banks & 3,519 & 3,519 & 3,519 & 3,519 & 3,519 & 3,519 \\
\hline R-squared & 0.017 & 0.019 & 0.013 & 0.018 & 0.020 & 0.015 \\
\hline
\end{tabular}

Note: Time effects not reported. Robust standard errors in parentheses, ${ }^{* * *},{ }^{* *}$, and ${ }^{*}$ denote significance at $1 \%, 5 \%$, and $10 \%$ level, respectively. 
In the second step, we add the institutional variables in specifications (4) to (6). These variables have a significant and positive impact on bank loans in specifications (4) to (6), while monetary freedom is insignificant in specification (5). As a result, loan growth is higher in countries with higher institutional quality.

In all specifications, the variable loan-rate spread is significant with a negative impact on bank lending activities. Thus, higher interest rates are associated with a lower supply of loans. When the spread increases, the interest rates for borrowers, set by an individual bank, diverge from the average money market interest rate in the country which can be due to a rising perceived risk in the economy. As such, loan-rate spread shows the role of supply factors.

However, loans spreads are likely to be endogenous because they can be influenced by country risk and economic conditions as well. As proposed by Bassett (2014), we use main bank indicators on asset quality as instruments for loan-rate spread in order to identify the exogenous individual supply factors of bank specific lending development. In particular, we select Tier 1 and share of impaired loans as instrumental variables because these variables are a result of the past developments of the banks and regulatory changes which are not related directly to the current lending activity situation of the banks. Tier 1 represents the capital strength of the bank and plays an important role in bank solvency, related to its vulnerability in terms of unexpected losses and bankruptcy issues. In economic downturns banks' assets deteriorate and increase risk exposures. Due to the regulatory requirements the banks are forced to increase their core equity capital or cut their lending activities. Thus, bank's core equity capital is a very important determinant of the lending activity. Share of impaired loans is a result of past macroeconomic shocks and the previous lending policy.

We use 2SLS model with instrumental variables (Table 2) and compare the results of the fixed effect model estimated by least squares (Table 1). As before, we include the variables on macroeconomic shocks and institutions one-by-one in columns (1) to (5), and we present a full specification in column (6). According to our results, variables Tier 1 and share of impaired loans are significant in individual specifications (1) to (5). In case of Tier 1, it has a negative effect on loanrate spread, i.e. the higher the level of capital adequacy of a bank, the lower the risk and the lower the spread. The share of impaired loans has a positive impact on loan-rate spread, meaning that a higher share of impaired loans in the bank's portfolio of an individual bank increases the risk premium in the bank's interest rate. In specification (6), which contains all main explanatory variables, the variables Tier 1 and impaired loans/loans are also significant. In sum, the first stage regressions show that banks with a lower level of capital adequacy and a higher level of impaired loans have to compensate for the increased risk which leads to the increased level of spread. The variables defined on the country level are insignificant in the first stage regression. 
Table 2: Macroeconomic shocks and institutions: 2SLS fixed effects model, 2000-2013

\begin{tabular}{|c|c|c|c|c|c|c|}
\hline \multicolumn{7}{|c|}{ First-stage equation: Loan-rate spread } \\
\hline Independent Variables & (1) & (2) & (3) & (4) & (5) & (6) \\
\hline Tier I (ln) & $\begin{array}{c}-0.006^{*} \\
(0.004)\end{array}$ & $\begin{array}{c}-0.006^{*} \\
(0.004)\end{array}$ & $\begin{array}{c}-0.006^{*} \\
(0.004)\end{array}$ & $\begin{array}{c}-0.006^{*} \\
(0.004)\end{array}$ & $\begin{array}{c}-0.006^{*} \\
(0.004)\end{array}$ & $\begin{array}{c}-0.006^{*} \\
(0.004)\end{array}$ \\
\hline Share of impaired loans (ln) & $\begin{array}{l}0.005^{* * *} \\
(0.002)\end{array}$ & $\begin{array}{c}0.005^{* *} \\
(0.002)\end{array}$ & $\begin{array}{c}0.006^{* *} \\
(0.002)\end{array}$ & $\begin{array}{l}0.005^{* * *} \\
(0.002)\end{array}$ & $\begin{array}{c}0.005^{* *} \\
(0.002)\end{array}$ & $\begin{array}{l}0.005^{* *} \\
(0.002)\end{array}$ \\
\hline HICP (ln) & $\begin{array}{c}-0.002 \\
(0.002)\end{array}$ & $\begin{array}{c}-0.002 \\
(0.002)\end{array}$ & $\begin{array}{c}-0.002 \\
(0.002)\end{array}$ & $\begin{array}{c}-0.001 \\
(0.002)\end{array}$ & $\begin{array}{c}-0.001 \\
(0.002)\end{array}$ & $\begin{array}{c}-0.001 \\
(0.001)\end{array}$ \\
\hline GDP (ln) & $\begin{array}{c}0.004 \\
(0.019)\end{array}$ & & & $\begin{array}{c}0.002 \\
(0.017)\end{array}$ & & \\
\hline Consumption (ln) & & $\begin{array}{c}0.001 \\
(0.002)\end{array}$ & & & $\begin{array}{c}0.001 \\
(0.002)\end{array}$ & \\
\hline Unemployment (ln) & & & $\begin{array}{c}-0.004 \\
(0.007)\end{array}$ & & & $\begin{array}{c}-0.001 \\
(0.001)\end{array}$ \\
\hline Monetary freedom (ln) & & & & $\begin{array}{c}-0.003 \\
(0.003)\end{array}$ & $\begin{array}{c}-0.003 \\
(0.003)\end{array}$ & $\begin{array}{c}-0.003 \\
(0.003)\end{array}$ \\
\hline Investment freedom (ln) & & & & $\begin{array}{c}-0.001 \\
(0.002)\end{array}$ & $\begin{array}{c}-0.001 \\
(0.002)\end{array}$ & $\begin{array}{c}-0.001 \\
(0.001)\end{array}$ \\
\hline \multicolumn{7}{|c|}{ Second-stage equation: Gross Loans to Total Assets (ln) } \\
\hline Loan-rate spread & $\begin{array}{c}-43.284^{* *} \\
(20.342)\end{array}$ & $\begin{array}{c}-43.032^{* *} \\
(20.193)\end{array}$ & $\begin{array}{c}-41.679^{* *} \\
(19.866)\end{array}$ & $\begin{array}{c}-43.182^{* *} \\
(20.450)\end{array}$ & $\begin{array}{c}-42.897^{* *} \\
(20.291)\end{array}$ & $\begin{array}{c}-41.675^{* *} \\
(19.983)\end{array}$ \\
\hline HICP (ln) & $\begin{array}{c}0.320^{* *} \\
(0.137)\end{array}$ & $\begin{array}{l}0.432^{* * *} \\
(0.132)\end{array}$ & $\begin{array}{l}0.581^{* * *} \\
(0.135)\end{array}$ & $\begin{array}{c}0.346^{* *} \\
(0.141)\end{array}$ & $\begin{array}{l}0.457^{* * *} \\
(0.136)\end{array}$ & $\begin{array}{l}0.599^{* * *} \\
(0.139)\end{array}$ \\
\hline GDP (ln) & $\begin{array}{l}0.633^{* * *} \\
(0.124)\end{array}$ & & & $\begin{array}{l}0.620^{* * *} \\
(0.122)\end{array}$ & & \\
\hline Consumption (ln) & & $\begin{array}{l}0.667^{* * *} \\
(0.116)\end{array}$ & & & $\begin{array}{l}0.655^{* * *} \\
(0.114)\end{array}$ & \\
\hline Unemployment (ln) & & & $\begin{array}{c}-0.112^{* * *} \\
(0.024)\end{array}$ & & & $\begin{array}{c}-0.110^{* * *} \\
(0.024)\end{array}$ \\
\hline Monetary freedom (ln) & & & & $\begin{array}{c}0.069 \\
(0.138)\end{array}$ & $\begin{array}{c}0.044 \\
(0.139)\end{array}$ & $\begin{array}{c}0.041 \\
(0.142)\end{array}$ \\
\hline Investment freedom (ln) & & & & $\begin{array}{c}-0.061 \\
(0.067)\end{array}$ & $\begin{array}{c}-0.066 \\
(0.066)\end{array}$ & $\begin{array}{c}-0.055 \\
(0.061)\end{array}$ \\
\hline Year-specific dummies & YES & YES & YES & YES & YES & YES \\
\hline Number of Obs. & 8,371 & 8,371 & 8,373 & 8,371 & 8,371 & 8,373 \\
\hline Number of Banks & 1,887 & 1,887 & 1,887 & 1,887 & 1,887 & 1,887 \\
\hline Kleibergen-Paap LM statistic & 6.816 & 6.58 & 5.306 & 6.932 & 6.665 & 5.406 \\
\hline Chi-sq P-value & 0.033 & 0.037 & 0.07 & 0.031 & 0.036 & 0.067 \\
\hline Hansen J statistic & 0.475 & 0.299 & 0.125 & 0.444 & 0.282 & 0.121 \\
\hline Chi-sq P-value & 0.491 & 0.584 & 0.724 & 0.505 & 0.595 & 0.728 \\
\hline
\end{tabular}

Note: Loan-rate spread is instrumented by Tier I (ln) and Share of impaired loans (ln). Time effects not reported. Robust standard errors in parentheses, ${ }^{* * *},{ }^{* *}$, and ${ }^{*}$ denote significance at $1 \%, 5 \%$, and $10 \%$ level, respectively. 
When we compare the results of the 2SLS regression (see Table 2, lower part) to those of OLS (Table 1), we can see that the impact of loan-rate spread on bank lending activities is much higher when using the 2SLS estimation. This is consistent with a downward bias in the standard regression: higher loans lead to higher bank risk and to higher loan-rate spreads and thus to a lower OLS estimation coefficient.

In turn, demand factors (GDP, consumption, unemployment) are also highly significant. Nevertheless, the institutional variables are no longer significant in the 2SLS specifications. Overall, we can conclude that both supply and demand factors play a role in the process of providing bank loans in the analysed time period. 


\section{Robustness Analysis}

We check the sensitivity of our analysis in two ways. Firstly, we show that our results remain largely unchanged if we analyse separately large and small banks (see Table 3). In particular, we use two thresholds to identify large banks: a bank is considered large when its total assets exceed the median size or even the upper tertile of assets of all banks in the analysed countries, respectively. In case of loan-rate spread, the negative impact of this variable on the dependent variable is significantly higher for large banks compared to small banks. Thus, large banks incorporate a possible risk in the interest rates at a higher degree than small banks. Hence, supply factors are particularly important for the lending mechanism of large banks.

Moreover, the loans of large banks depend strongly also on demand factors like GDP, consumption or unemployment. However, our analysis shows different results for institutional variables: Monetary freedom is significant for small banks, while investment freedom for large banks. Similarly, price stability (using the HICP variable) is more important for small banks than for large. As a result, monetary disruptions can negatively influence especially the lending activity of small European banks. In turn, restrictions imposed on investment activity could have a negative impact on the lending activities of large banks.

Second, we perform our analysis for the period before and after the financial crisis (i.e. before and after 2007). The upper part of Table 4 presents the results of the first stage-regression with the dependent variable loan-rate spread. We identify a negative and significant effect of capital adequacy and a positive and partly significant, in specifications (4) and (5), effect of impaired loans on the spread in the post-crisis period. Therefore, banks have been more cautious, as far as the potential risk is concerned, since the financial crisis. On the other hand, demand factors (GDP and consumption) are significant in the pre-crisis period.

In the lower part of Table 4, we can see that the impact of the loan-rate spread on lending activity of banks is apparently more significant in the period after the crisis than before the crisis. As far as macroeconomic shocks are concerned, the variables GDP and consumption still have a significant and positive impact on the dependent variable in the post-crisis period, while unemployment proves to be significant in both periods. 
Table 3: Impact of shocks on large and small banks, fixed effects model, 2000-2013

\begin{tabular}{|c|c|c|c|c|c|c|}
\hline \multirow[b]{3}{*}{ Independent Variables } & \multicolumn{6}{|c|}{ Dependent variable: Gross Loans to Total Assets (ln), 2000-2013 } \\
\hline & \multicolumn{3}{|c|}{ large banks over asset median } & \multicolumn{3}{|c|}{ large banks in the highest asset tertile } \\
\hline & (1) & (2) & (3) & (4) & (5) & (6) \\
\hline $\begin{array}{l}\text { Loan-rate spread } \\
\text { (small banks) }\end{array}$ & $\begin{array}{l}-0.002^{* * *} \\
(0.000)\end{array}$ & $\begin{array}{l}-0.002^{* * *} \\
(0.000)\end{array}$ & $\begin{array}{l}-0.002^{* * *} \\
(0.000)\end{array}$ & $\begin{array}{l}-0.002^{* * *} \\
(0.000)\end{array}$ & $\begin{array}{l}-0.002^{* * *} \\
(0.000)\end{array}$ & $\begin{array}{l}-0.002^{* * *} \\
(0.000)\end{array}$ \\
\hline $\begin{array}{l}\text { Loan-rate spread } \\
\text { (large banks) }\end{array}$ & $\begin{array}{l}-0.086^{* *} \\
(0.041)\end{array}$ & $\begin{array}{l}-0.085^{* *} \\
(0.040)\end{array}$ & $\begin{array}{l}-0.086^{* *} \\
(0.041)\end{array}$ & $\begin{array}{l}-0.083^{* *} \\
(0.041)\end{array}$ & $\begin{array}{l}-0.083^{* *} \\
(0.041)\end{array}$ & $\begin{array}{l}-0.084^{* *} \\
(0.041)\end{array}$ \\
\hline $\begin{array}{l}\text { HICP }(\ln ) \\
\text { (small banks) }\end{array}$ & $\begin{array}{l}0.763^{* * *} \\
(0.218)\end{array}$ & $\begin{array}{l}0.818^{* * *} \\
(0.227)\end{array}$ & $\begin{array}{l}0.996^{* * *} \\
(0.218)\end{array}$ & $\begin{array}{l}0.594^{* * *} \\
(0.215)\end{array}$ & $\begin{array}{l}0.606^{* * *} \\
(0.224)\end{array}$ & $\begin{array}{l}0.946^{* * *} \\
(0.220)\end{array}$ \\
\hline $\begin{array}{l}\text { HICP (ln) } \\
\text { (large banks) }\end{array}$ & $\begin{array}{l}0.537^{* * *} \\
(0.177)\end{array}$ & $\begin{array}{l}0.508^{* * *} \\
(0.176)\end{array}$ & $\begin{array}{l}1.036^{* * *} \\
(0.201)\end{array}$ & $\begin{array}{l}0.607^{* * *} \\
(0.176)\end{array}$ & $\begin{array}{l}0.585^{* * *} \\
(0.172)\end{array}$ & $\begin{array}{l}1.066^{* * *} \\
(0.202)\end{array}$ \\
\hline $\begin{array}{l}\text { GDP }(\ln ) \\
\text { (small banks) }\end{array}$ & $\begin{array}{l}0.409^{* * *} \\
(0.131)\end{array}$ & & & $\begin{array}{l}0.593^{* * *} \\
(0.122)\end{array}$ & & \\
\hline $\begin{array}{l}\text { GDP (ln) } \\
\text { (large banks) }\end{array}$ & $\begin{array}{l}0.848^{* * *} \\
(0.131)\end{array}$ & & & $\begin{array}{l}0.790^{* * *} \\
(0.151)\end{array}$ & & \\
\hline $\begin{array}{l}\text { Consumption (ln) } \\
\text { (small banks) }\end{array}$ & & $\begin{array}{l}0.372^{* *} \\
(0.158)\end{array}$ & & & $\begin{array}{l}0.642^{* * *} \\
(0.139)\end{array}$ & \\
\hline $\begin{array}{l}\text { Consumption (ln) } \\
\text { (large banks) }\end{array}$ & & $\begin{array}{l}1.013^{* * *} \\
(0.135)\end{array}$ & & & $\begin{array}{l}0.925^{* * *} \\
(0.162)\end{array}$ & \\
\hline $\begin{array}{l}\text { Unemployment (ln) } \\
\text { (small banks) }\end{array}$ & & & $\begin{array}{c}0.008 \\
(0.019)\end{array}$ & & & $\begin{array}{l}-0.020 \\
(0.018)\end{array}$ \\
\hline $\begin{array}{l}\text { Unemployment (ln) } \\
\text { (large banks) }\end{array}$ & & & $\begin{array}{l}-0.087^{* * *} \\
(0.019)\end{array}$ & & & $\begin{array}{l}-0.090^{* * *} \\
(0.021)\end{array}$ \\
\hline $\begin{array}{l}\text { Monetary freedom (ln) } \\
\text { (small banks) }\end{array}$ & $\begin{array}{l}0.434^{* * *} \\
(0.136)\end{array}$ & $\begin{array}{l}0.440^{* * *} \\
(0.140)\end{array}$ & $\begin{array}{l}0.376^{* * *} \\
(0.139)\end{array}$ & $\begin{array}{l}0.357^{* * *} \\
(0.132)\end{array}$ & $\begin{array}{l}0.310^{* *} \\
(0.135)\end{array}$ & $\begin{array}{l}0.362^{* * *} \\
(0.133)\end{array}$ \\
\hline $\begin{array}{l}\text { Monetary freedom (ln) } \\
\text { (large banks) }\end{array}$ & $\begin{array}{c}0.109 \\
(0.130)\end{array}$ & $\begin{array}{l}-0.006 \\
(0.133)\end{array}$ & $\begin{array}{c}0.270^{* *} \\
(0.123)\end{array}$ & $\begin{array}{c}0.070 \\
(0.141)\end{array}$ & $\begin{array}{l}-0.036 \\
(0.147)\end{array}$ & $\begin{array}{c}0.197 \\
(0.133)\end{array}$ \\
\hline $\begin{array}{l}\text { Investment freedom (ln) } \\
\text { (small banks) }\end{array}$ & $\begin{array}{c}0.048 \\
(0.052)\end{array}$ & $\begin{array}{c}0.025 \\
(0.052)\end{array}$ & $\begin{array}{c}0.023 \\
(0.054)\end{array}$ & $\begin{array}{c}0.082 \\
(0.056)\end{array}$ & $\begin{array}{c}0.054 \\
(0.057)\end{array}$ & $\begin{array}{c}0.072 \\
(0.057)\end{array}$ \\
\hline $\begin{array}{l}\text { Investment freedom (ln) } \\
\text { (large banks) }\end{array}$ & $\begin{array}{l}0.155^{* * *} \\
(0.046)\end{array}$ & $\begin{array}{l}0.128^{* * *} \\
(0.047)\end{array}$ & $\begin{array}{l}0.184^{* * *} \\
(0.046)\end{array}$ & $\begin{array}{l}0.150^{* * *} \\
(0.051)\end{array}$ & $\begin{array}{l}0.128^{* *} \\
(0.052)\end{array}$ & $\begin{array}{l}0.185^{* * *} \\
(0.054)\end{array}$ \\
\hline Constant & $\begin{array}{l}-3.395^{* * *} \\
(0.973)\end{array}$ & $\begin{array}{l}-3.430^{* * *} \\
(0.960)\end{array}$ & $\begin{array}{l}-2.288^{* *} \\
(0.902)\end{array}$ & $\begin{array}{l}-3.265^{* * *} \\
(0.987)\end{array}$ & $\begin{array}{l}-3.252^{* * *} \\
(0.977)\end{array}$ & $\begin{array}{l}-2.090^{* *} \\
(0.911)\end{array}$ \\
\hline Year-specific dummies & YES & YES & YES & YES & YES & YES \\
\hline Number of Obs. & 33,326 & 33,326 & 33,338 & 33,326 & 33,326 & 33,338 \\
\hline Number of Banks & 3,519 & 3,519 & 3,519 & 3,519 & 3,519 & 3,519 \\
\hline R-squared & 0.028 & 0.030 & 0.025 & 0.027 & 0.028 & 0.024 \\
\hline
\end{tabular}

Note: Time effects not reported. Robust standard errors in parentheses, ${ }^{* * *}{ }^{* *}$, and ${ }^{*}$ denote significance at $1 \%, 5 \%$, and $10 \%$ level, respectively. 
Table 4: Macroeconomic shock and the impact of the crisis, 2SLS fixed effects model

\begin{tabular}{|c|c|c|c|c|c|c|}
\hline \multicolumn{7}{|c|}{ First-stage equation, Loan-rate spread } \\
\hline & \multicolumn{3}{|c|}{ 2000-2006 } & \multicolumn{3}{|c|}{ 2007-2013 } \\
\hline & (1) & (2) & (3) & (4) & (5) & (6) \\
\hline Tier I (ln) & $\begin{array}{l}-0.017 \\
(0.011)\end{array}$ & $\begin{array}{c}-0.015 \\
(0.011)\end{array}$ & $\begin{array}{c}-0.015 \\
(0.011)\end{array}$ & $\begin{array}{l}-0.010^{* *} \\
(0.004)\end{array}$ & $\begin{array}{l}-0.011^{* *} \\
(0.004)\end{array}$ & $\begin{array}{l}-0.011^{* *} \\
(0.004)\end{array}$ \\
\hline Share of impaired loans (ln) & $\begin{array}{c}0.021 \\
(0.022)\end{array}$ & $\begin{array}{c}0.030 \\
(0.023)\end{array}$ & $\begin{array}{r}0.037^{*} \\
(0.022)\end{array}$ & $\begin{array}{r}0.066^{*} \\
(0.036)\end{array}$ & $\begin{array}{r}0.068^{*} \\
(0.039)\end{array}$ & $\begin{array}{c}0.073 \\
(0.046)\end{array}$ \\
\hline HICP (ln) & $\begin{array}{c}0.009 \\
(0.006)\end{array}$ & $\begin{array}{c}0.007 \\
(0.006)\end{array}$ & $\begin{array}{l}-0.001 \\
(0.007)\end{array}$ & $\begin{array}{c}0.002 \\
(0.003)\end{array}$ & $\begin{array}{c}0.003 \\
(0.004)\end{array}$ & $\begin{array}{c}0.002 \\
(0.004)\end{array}$ \\
\hline GDP (ln) & $\begin{array}{l}-0.013^{* *} \\
(0.005)\end{array}$ & & & $\begin{array}{c}0.003 \\
(0.003)\end{array}$ & & \\
\hline Consumption (ln) & & $\begin{array}{c}-0.008^{*} \\
(0.004)\end{array}$ & & & $\begin{array}{c}0.004 \\
(0.004)\end{array}$ & \\
\hline Unemployment (ln) & & & $\begin{array}{l}-0.004 \\
(0.017)\end{array}$ & & & $\begin{array}{c}0.011 \\
(0.014)\end{array}$ \\
\hline \multicolumn{7}{|c|}{ Second-stage equation, Gross Loans to Total Assets (In) } \\
\hline & \multicolumn{2}{|c|}{ 2000-2006 } & & \multicolumn{2}{|c|}{ 2007-2013 } & \\
\hline Loan-rate spread & $\begin{array}{l}-54.277 \\
(45.089)\end{array}$ & $\begin{array}{l}-55.059 \\
(45.124)\end{array}$ & $\begin{array}{l}-51.635 \\
(41.603)\end{array}$ & $\begin{array}{l}-36.837^{* * *} \\
(12.187)\end{array}$ & $\begin{array}{l}-36.289^{* * *} \\
(12.008)\end{array}$ & $\begin{array}{l}-35.525^{* * *} \\
(12.010)\end{array}$ \\
\hline HICP (ln) & $\begin{array}{c}0.356 \\
(0.683)\end{array}$ & $\begin{array}{c}0.350 \\
(0.650)\end{array}$ & $\begin{array}{l}-0.167 \\
(0.483)\end{array}$ & $\begin{array}{c}0.238 \\
(0.217)\end{array}$ & $\begin{array}{r}0.420^{*} \\
(0.227)\end{array}$ & $\begin{array}{r}0.418^{*} \\
(0.232)\end{array}$ \\
\hline GDP $(\ln )$ & $\begin{array}{c}0.121 \\
(0.624)\end{array}$ & & & $\begin{array}{l}0.550^{* * *} \\
(0.125)\end{array}$ & & \\
\hline Consumption (ln) & & $\begin{array}{c}0.128 \\
(0.501)\end{array}$ & & & $\begin{array}{l}0.633^{* * *} \\
(0.124)\end{array}$ & \\
\hline Unemployment (ln) & & & $\begin{array}{c}-0.194^{*} \\
(0.113)\end{array}$ & & & $\begin{array}{c}-0.119^{* * *} \\
(0.029)\end{array}$ \\
\hline Year-specific dummies & YES & YES & YES & YES & YES & YES \\
\hline Number of Obs. & 510 & 510 & 513 & 7,575 & 7,575 & 7,575 \\
\hline Number of Banks & 193 & 193 & 194 & 1,865 & 1,865 & 1,865 \\
\hline Kleibergen-Paap LM statistic & 1.177 & 1.332 & 2.315 & 4.655 & 4.52 & 4.063 \\
\hline Chi-sq P-value & 0.555 & 0.514 & 0.314 & 0.098 & 0.104 & 0.131 \\
\hline Hansen J statistic & 0.249 & 0.201 & 0.007 & 0.170 & 0.036 & 0.001 \\
\hline Chi-sq P-value & 0.618 & 0.654 & 0.936 & 0.68 & 0.849 & 0.969 \\
\hline
\end{tabular}

Note: Loan-rate spread is instrumented by Tier I (ln) and Share of impaired loans (ln). Time effects not reported. Robust standard errors in parentheses, ${ }^{* * *}, * *$, and ${ }^{*}$ denote significance at $1 \%, 5 \%$, and $10 \%$ level, respectively. 


\section{Conclusions}

In nearly all European countries, bank loans are the most important source of capital. Therefore, the supply of loans has a crucial importance for the economic development and, in particular, for the recovery from the financial crisis. In order to shed more light on this challenging issue, we analyse the link between macroeconomic shocks, the institutional environment and the responses of the banking sector to the financial crisis in the EU countries. We focus on the impact of loan-rate spreads and asset quality, which are found to be the main supply factors of bank lending activities in the EU. Indeed, we show that the loan-rate spread is the most important and statistically robust indicator of loan development. This finding is in line with Gambacorta and Marques-Ibanez (2011) who show that the bank risk is an important determinant influencing the supply of loans. This underlines the overwhelming importance of the supply factors for bank lending in EU. Additionally, the supply factors seem to be especially important for large banks, while small banks are more sensitive to demand developments.

However, our results show that macroeconomic shocks, (GDP, HICP, consumption and unemployment rate) which proxy mainly demand factors, have also a significant impact on bank lending activities of the EU countries within the analysed time period. Moreover, selected institutional variables also influence bank lending. Not surprisingly, monetary disorder is influencing especially the lending behaviour of small banks. This evidence is consistent with Kishan and Opiela (2000) and Kashyap and Stein (1995 and 2000) who argue that small banks respond more actively to monetary policy actions.

Our results remain largely robust to the inclusion of bank-specific control variables in the instrumental regression. Similarly to Popov and Udel (2012) and Berrospide and Edge (2010), our results show that bank capitalization (Tier 1 capital) has a positive effect on loan-rate spreads and thus also on loan development, while the ratio of impaired loans relatively to total loans of individual banks has a negative effect. 


\section{References}

Allen, L.O., 1988. The determinants of bank interest margins: a note. Journal of Financial and Quantitative Analysis, 23 (2), 231-235.

Altunbas, Y., Gambacorta, L., Marques-Ibanez, D., 2010. Bank risk and monetary policy. Journal of Financial Stability, 6 (3), 121-129.

Asea, P. K., Blomberg, B., 1998. Lending cycles. Journal of Econometrics, 83 (1-2), 89-128.

Barajas, A., Cosimano, T., Hakura, D., Roelands, S., 2015. The Role of Bank Capital in Bank Holding Companies’ Decisions. International Monetary Fund Working Paper 15/57.

Barro, R.J., Grossman, H.I., 1971. A General Disequilibrium Model of Income and Employment. American Economic Review, 61 (1), 82-93.

Bassett, W.F., Chosak, M.B., Driscoll, J.C., Zakrajšek, E., 2014. Changes in bank lending standards and the macroeconomy. Journal of Monetary Economics, 62 (March 2014), 23-40.

Benassy, J.P., 1975. Neo-Keynesian Disequilibrium Theory in a Monetary Economy. Review of Economic Studies, 42 (4), 503-523.

Beck, T., Levine, R., 2002. Industry Growth and Capital Allocation: Does Having a Market- or Bank-Based System Matter? Journal of Financial Economics, 64 (2), 147-180.

Berger, A.N., Udell, G.F., 2004. The institutional memory hypothesis and the procyclicality of bank lending behaviour. Journal of Financial Intermediation, 13 (4), 458-495.

Berrospide, J.M., Edge, R.M., 2010. The Effects of Bank Capital on Lending: What Do We Know, and What Does It Mean? Finance and Economics Discussion Series, Federal Reserve Board. Washington, D.C. No. 2010-44.

Brunnermeier, M., 2009. Deciphering the Liqudity and Credit Crunch 2007-8. Journal of Economic Perspectives, 23 (1), 77-100.

Brunnermeier, M., Pedersen, L., 2009. Market Liquidity and Funding Liquidity. Review of Financial Studies, 22 (6), 2201-2238.

Calvo, G.A., 2009. Financial Crises and Liquidity Shocks: A Bank-Run Perspective. NBER Working Paper No. 15425.

Clower, R.W., 1965. The Keynesian Counter Revolution: A Theoretical Appraisal. In Hahn, F.H. and Brechling, F. (eds): The Theory of Interest Rates. London: Macmillan.

Cosimano, T., Hakura, D., 2011. Bank Behavior in Response to Basel III: A Cross-Country Analysis. International Monetary Fund Working Paper 11/119.

deBondt, G., Marques-Ibanez, D., 2005. High-yield bond diffusion in the United States, the United Kingdom and the Euro Area. Journal of Financial Services Research, 27 (2), 163-181.

de Mello, L., Pisu, M., 2010. The bank lending channel of monetary transmission in Brazil: A VECM approach. The Quarterly Review of Economics and Finance, 50 (1), 50-60.

Djankov, S., McLiesh, C., Shleifer, A., 2007. Private credit in 129 countries. Journal of Financial Economics, 84 (2), 299-329.

Djankov, S., Hart, O., McLiesh, C., Shleifer, A., 2008. Debt enforcement around the world. Journal of Political Economy, 116 (6), 1105-1149. 
Drèze, J.H., 1975. Existence of an Exchange Equilibrium Under Price Rigidities. International Economic Review, 16 (2), 301-320.

Entrop, O., Memmel, C., Ruprecht, B., Wilkens, M., 2015. Determinants of bank interest margins: Impact of maturity transformation. Journal of Banking and Finance, 54 (May 2015), 1-19.

Eurostat, 2015. Data [online]. [2015-11-10]. Available from: http://ec.europa.eu/eurostat/data/ database.

Fidrmuc, J., Siddiqui, M., Schreiber, P. 2015. The transmission of bank funding to corporate loans: Deleveraging in Germany. Open Economies Review, 26 (3), 581-597.

Fratzscher, M., 2012. Capital flows, push versus pull factors and the global financial crisis. Journal of International Economics, 88 (2), 341-356.

Gambacorta, L., Marques-Ibanez, D., 2011. The bank lending channel: lessons from the crisis. Economic Policy, 26 (66), 135-182.

Hansen, L.P., 1982. Large Sample Properties of Generalised Method of Moments Estimators. Econometrica, 50 (4), 1029-1054.

Ho, T., Saunders, A., 1981. The determinants of bank interest margins: theory and empirical evidence. Journal of Financial and Quantitative Analysis, 16 (4), 581-600.

Hülsewig, O., Mayer, E., Wollmershäuser, T., 2006. Bank loan supply and monetary policy transmission in Germany: An assessment based on matching impulse responses. Journal of Banking and Finance, 30 (10), 2893-2910.

Kalemli-Ozcan, S., Papaioannou, E., Perri, F., 2013. Global banks and crisis transmission. Journal of International Economics, 89, 495-510.

Kashyap, A.K., Stein, J.C., 1995. The Impact of Monetary Policy on Bank Balance Sheets. National Bureau of Economic Research Working Paper, 4821.

Kashyap, A.K., Stein, J.C., 2000. What Do a Million Banks Have to Say about the Transmission of Monetary Policy? The American Economic Review, 90 (3), 407-428.

Kleibergen, F., Paap, R., 2006. Generalized Reduced Rank Tests Using the Singular Value Decomposition. Journal of Econometrics, 133, 97-126.

Kishan, R.P., Opiela, T.P., 2000. Bank Size, Bank Capital, and the Bank Lending Channel. Journal of Money, Credit, and Banking, 32 (1), pp. 121-141.

Loutskina, E., Strahan, P., 2009. Securitization and the declining impact of bank finance on loan supply: evidence from mortgage originations. Journal of Finance, 64 (2), 861-889.

Maddala, G., Nelson, F., 1974. Maximum likelihood methods for models of market disequilibrium. Econometrica, 42 (6), pp. 1013-1030.

Popov, A., Udell, G.F., 2012. Cross-border banking, credit access, and the financial crisis. Journal of International Economics, 87 (1), 147-161.

Rajan, R., 1994. Why bank credit policies fluctuate: a theory and some evidence. The Quarterly Journal of Economics, 109 (2), 399-441.

Raiser, M., Di Tomasso M.L., Weeks M., 2000. The Measurement and Determinants of Institutional Change: Evidence from Transition Economies. European Bank for Reconstruction and Development Working Paper No. 60. 
Ruckes, M.E., 2004. Bank competition and credit standards. Review of Financial Studies, 17 (4), 1073-1102.

Uzunkaya, M., 2012. Economic Performance in Bank-Based and Market-Based Financial Systems: Do Non-Financial Institutions Matter? Journal of Applied Finance and Banking, 2 (5), 159-176.

Were, M., Wambua, J., 2014. What factor drive interest rate spread of commercial banks? Empirical evidence from Kenya. Review of Development Finance, 4 (2), 73-82. 


\section{Appendix}

\section{Table A1: Definition of Analysed Variables}

\begin{tabular}{|c|c|}
\hline Name and Source & Definition \\
\hline $\begin{array}{l}\text { GDP } \\
\text { Eurostat } \\
\text { http://ec.europa.eu/eurostat/data/database }\end{array}$ & $\begin{array}{l}\text { Gross domestic product at market prices (National accounts indicators, ESA } \\
\text { 2010, Code B1GQ). }\end{array}$ \\
\hline $\begin{array}{l}\text { Consumption } \\
\text { Eurostat } \\
\text { http://ec.europa.eu/eurostat/data/database }\end{array}$ & $\begin{array}{l}\text { Final consumption expenditure at market prices (National accounts indicators, } \\
\text { ESA 2010, Code P3). }\end{array}$ \\
\hline $\begin{array}{l}\text { Investment } \\
\text { Eurostat } \\
\text { http://ec.europa.eu/eurostat/data/database }\end{array}$ & $\begin{array}{l}\text { Gross capital formation at market prices (National accounts indicators, ESA } \\
\text { 2010, Code PG5). }\end{array}$ \\
\hline $\begin{array}{l}\text { Unemployment } \\
\text { World Bank } \\
\text { World Development Indicators } \\
\text { http://databank.worldbank.org/data/reports.aspx? } \\
\text { source=world-development-indicators }\end{array}$ & $\begin{array}{l}\text { Unemployment refers to the share of the labour force that is without work but } \\
\text { available for and seeking employment (percentage of total labour force, ILO } \\
\text { Global Estimate of Forced Labour 2012). }\end{array}$ \\
\hline $\begin{array}{l}\text { HICP } \\
\text { Eurostat } \\
\text { http://ec.europa.eu/eurostat/data/database }\end{array}$ & $\begin{array}{l}\text { Harmonised index of consumer prices measures the change over time of the } \\
\text { prices of consumer goods and services acquired by households. It is a set of } \\
\text { consumer price indices (CPI) calculated according to a harmonised approach } \\
\text { and a single set of definitions (Annual average index, 2000=100). }\end{array}$ \\
\hline $\begin{array}{l}\text { Monetary Freedom, } \\
\text { Comp. of Economic Freedom Index } \\
\text { http://www.heritage.org/index/explore }\end{array}$ & $\begin{array}{l}\text { Monetary freedom combines price stability (weighted average inflation for } \\
\text { previous three years) with an assessment of price controls (a penalty up to } \\
20 \% \text { if price controls are important). }\end{array}$ \\
\hline $\begin{array}{l}\text { Investment Freedom, } \\
\text { Comp. of Economic Freedom Index } \\
\text { http://www.heritage.org/index/explore }\end{array}$ & $\begin{array}{l}\text { The index evaluates the severity of restrictions related to investment including } \\
\text { rules for foreign and domestic investment, restrictions on payments, transfers, } \\
\text { foreign exchange and capital transactions, labour regulations, corruption, red } \\
\text { tape, weak infrastructure, and political and security conditions. }\end{array}$ \\
\hline $\begin{array}{l}\text { Loan-rate spread } \\
\text { Bankscope Database }\end{array}$ & $\begin{array}{l}\text { Difference between interest income to gross loans (of individual banks) and } \\
\text { money market interest rates. }\end{array}$ \\
\hline $\begin{array}{l}\text { Tier } 1 \\
\text { Bankscope Database }\end{array}$ & $\begin{array}{l}\text { Shareholder funds plus perpetual non-cumulative preference shares as a per- } \\
\text { centage of risk weighted assets and off balance sheet risks measured under the } \\
\text { Basel rules. }\end{array}$ \\
\hline $\begin{array}{l}\text { Liquid assets to deposits } \\
\text { Bankscope Database }\end{array}$ & $\begin{array}{l}\text { Liquid assets to deposits and Short term funding ratio looks at the amount of } \\
\text { liquid assets available to borrower as well as depositors. }\end{array}$ \\
\hline $\begin{array}{l}\text { Impaired loans to gross loans } \\
\text { Bankscope Database }\end{array}$ & $\begin{array}{l}\text { Impaired loans as per the accounts according to the Universal Bank Model. It } \\
\text { represents a percentage share of the total value of the loans that have a spe- } \\
\text { cific impairment against gross loans. }\end{array}$ \\
\hline $\begin{array}{l}\text { Equity to total assets } \\
\text { Bankscope Database }\end{array}$ & $\begin{array}{l}\text { Equity-to-asset ratio is an investment leverage or solvency ratio that measures } \\
\text { the amount of assets that are financed by owners' investments by comparing } \\
\text { the total equity in the bank to the total assets. Equity includes common shares } \\
\text { and premium, retained earnings, reserves for general banking risks and statu- } \\
\text { tory reserves. }\end{array}$ \\
\hline
\end{tabular}


Table A2: Descriptive statistics

\begin{tabular}{|c|c|c|c|c|c|}
\hline Variables in logs & Obs & Mean & Std. Dev. & Min & Max \\
\hline Gross loans & 8765 & 4.094 & 0.395 & 0.225 & 4.893 \\
\hline Loan-rate spread & 8765 & 0.004 & 0.005 & -0.008 & 0.337 \\
\hline Tier I & 8765 & 14.086 & 6.900 & 0.000 & 98.000 \\
\hline Share of impaired loans & 8765 & 6.738 & 6.473 & 0.001 & 92.788 \\
\hline HICP & 8765 & 4.718 & 0.061 & 4.335 & 5.028 \\
\hline GDP & 8765 & 4.587 & 0.052 & 3.998 & 4.787 \\
\hline Investment & 8765 & 4.472 & 0.135 & 3.414 & 4.780 \\
\hline Consumption & 8765 & 4.610 & 0.050 & 4.019 & 4.761 \\
\hline Unemployment & 8765 & 4.690 & 0.413 & 4.121 & 6.026 \\
\hline Monetary freedom & 8765 & 4.398 & 0.035 & 4.199 & 4.545 \\
\hline Investment freedom & 8765 & 4.346 & 0.121 & 3.912 & 4.554 \\
\hline Variables in original units & Obs & Mean & Std. Dev. & Min & Max \\
\hline Gross loans to total assets & 8765 & 63.517 & 17.508 & 1.253 & 133.413 \\
\hline HICP & 8765 & 112.196 & 6.997 & 76.360 & 152.610 \\
\hline GDP & 8765 & 98.347 & 4.976 & 54.501 & 119.948 \\
\hline Investment & 8765 & 88.271 & 10.785 & 30.394 & 119.119 \\
\hline Consumption & 8765 & 100.620 & 4.882 & 55.669 & 116.919 \\
\hline Unemployment & 8765 & 118.593 & 51.166 & 61.628 & 413.954 \\
\hline Monetary freedom & 8765 & 81.306 & 2.760 & 66.600 & 94.200 \\
\hline Investment freedom & 8765 & 77.739 & 8.867 & 50.000 & 95.000 \\
\hline
\end{tabular}


Table A3: Correlation matrix

\begin{tabular}{|l|c|c|c|c|c|c|c|c|c|c|}
\hline & Loans & Spread & HICP & GDP & Invest & Cons & Unempl & MFree & IFree & Tier I \\
\hline Loan-rate spread & -0.074 & 1.000 & & & & & & & \\
HICP & 0.013 & 0.004 & 1.000 & & & & & & \\
Investment & 0.035 & 0.005 & 0.748 & 1.000 & & & & & \\
Consumption & 0.024 & 0.002 & 0.299 & 0.679 & 1.000 & & & & \\
Unemployment & 0.067 & 0.005 & 0.706 & 0.937 & 0.703 & 1.000 & & & \\
Monetary freedom & -0.011 & -0.010 & -0.033 & -0.293 & -0.583 & -0.328 & 1.000 & & \\
Investment freedom & 0.055 & 0.001 & -0.042 & 0.050 & 0.383 & 0.188 & -0.173 & 1.000 & \\
Tier I & 0.000 & 0.002 & 0.274 & 0.293 & 0.209 & 0.377 & -0.158 & 0.149 & 1.000 \\
Impaired Loans & 0.082 & 0.057 & -0.039 & -0.061 & -0.070 & -0.072 & 0.093 & -0.055 & -0.030 & 1.000 \\
\end{tabular}

